\title{
Re-implant of the right coronary artery: a surgical technique for the treatment of ostial lesions
}

\author{
Reimplante de artéria coronaria direita: uma técnica cirúrgica para o tratamento da lesão ostial
}

Hércules Lisboa BONGIOVANI*, Jorge Luís HADDAD**

RBCCV 44205-609

\begin{abstract}
Previously described surgical treatment for ostial coronary artery stenosis relied on either venous or arterial bypasses or ostial patch angioplasty. These surgical procedures are performed with bovine pericardium, saphenous vein or internal thoracic artery. We describe a technique of right coronary artery re-implantation into the aorta. The procedure was performed in four patients with right coronary artery ostial stenosis along with other left coronary artery lesions.
\end{abstract}

Descriptors: Myocardial revascularization, methods. Coronary disease, surgery.

\section{INTRODUCTION}

Surgical techniques for the treatment of ostial lesions of the coronary arteries, with the exception of endarterectomy [1], utilize patches of autologous tissue (bovine pericardium) $[2,3]$ or homologous (saphenous vein [4] or internal thoracic artery [5]) to reconstruct the affected ostium. The utilization of homologous or autologous tissue patches helps intimal hyperplastia, thrombosis and calcification, compromising the immediate and / or late results. Re-implantation of the right coronary artery, by means of its section and its direct
Resumo: O tratamento cirúrgico da obstrução de óstio da artéria coronária direita é realizado mediante a utilização de enxertos venosos ou arteriais, endarterectomia ou, ainda, por meio da reconstrução ostial com retalhos de pericárdio bovino, veia safena ou artéria torácica interna. Os autores propõem uma técnica cirúrgica que consiste no reimplante da artéria coronária na aorta. Esta técnica foi utilizada em quatro pacientes multiarteriais, porém com lesão única ostial na artéria coronária direita.

Descritores: Revascularização miocárdica, métodos. Coronariopatia, cirurgia.
Work performed in the Cardiovascular Surgery Department - Irmandade da Santa Casa de Misericórdia de Araraquara. São Paulo, SP, Brazil.

* Head of the Cardiovascular Surgery Department - Irmandade da Santa

Casa de Misericórdia de Araraquara.

** Head of the Hemodynamics - Irmandade da Santa Casa de Misericórdia

de Araraquara.

Correspondence address: Hércules Lisboa Bongiovani. Rua José

Bonifácio, 704. Centro. Araraquara, SP, Brazil. CEP: 14801-150 anastomosis to the aorta, permits the formation of a new ostium with an adequate size and without interposition of tissue patches.

\section{METHOD}

The surgical procedure is performed under general anesthesia with etomidato, isoflurane and sufentanil, intermittently utilizing a cardiopulmonary bypass at normothermia and normothermic cardioplegic solution, at 20-minute intervals. The right coronary artery is dissected 
from the proximal third to the ostium, respecting the emerging branches and, subsequently it is sectioned immediately after the obstruction. The extreme ostium is closed using a metal clip and simple sutures of 6.0 polypropylene thread (Figure 1A).

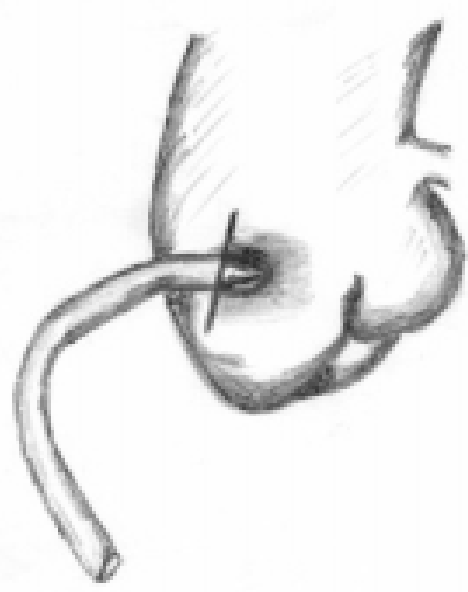

A

Fig. 1A - Section of coronary artery and closing of the ostium.

The anastomotic slot of the coronary artery is prepared by a vertical opening similar to the opening performed on segments of the saphenous vein used for bypasses. By means of a 4-mm punch, an orifice is created in the wall of the aorta, in a posterosuperior position in relation to the original ostium. Anastomosis is effected through continuous sutures using 7.0 polypropylene thread (Figure 1B).

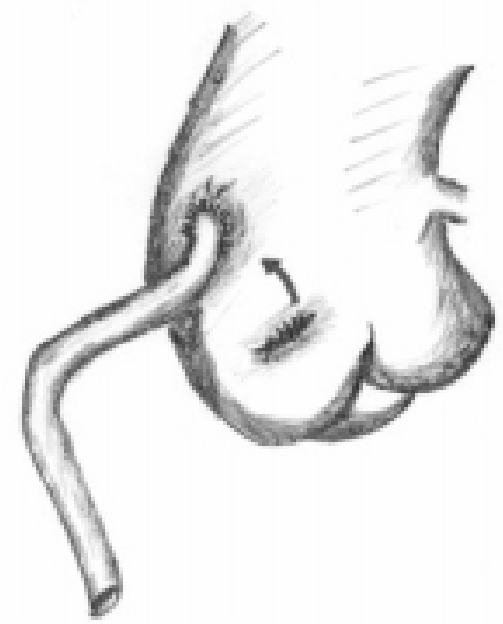

B

Fig. 1B - Anastomosis of the coronary artery.
The technique was employed in four patients who presented with obstructions in the left coronary artery and a severe isolated obstruction of the right coronary artery sited in the ostium. In two patients anastomosis of the internal thoracic artery to the anterior descending artery was performed. In the third sequential anastomosis of the left internal thoracic artery to the descending and oblique arteries was performed. And in the forth anastomosis of the internal thoracic artery to the descending artery and a saphenous vein graft for the obtuse marginal branch of the circumflex artery were effected.

\section{RESULTS}

The four patients had an event-free post-operative period, without enzymatic alterations and they were transferred from the intensive care unit to the ward 48 hours after surgery. In all the patients, a platelet anti-aggregant regime of $325 \mathrm{mg}$ acetylsalicylic acid was used.

The follow-up varied from 6 to 18 months, with the patients being re-evaluated every three months by exercise testing and myocardial scintigraphy, both of which gave no evidence of ischemia in the revascularized regions. Two patients were submitted to control cinecoronariography, 12 months after the procedure, demonstrating the permeability of the re-implant. In Figure 2A the pre-operative coronary angiography of one of the patients demonstrating the lesion of the right coronary artery ostium. Catheterism performed 12 months after the surgery evidencing the implanted right coronary artery with the aperture of the ostium greater than the reference diameter considered in the initial segment of the re-implanted artery (Figure 2B).

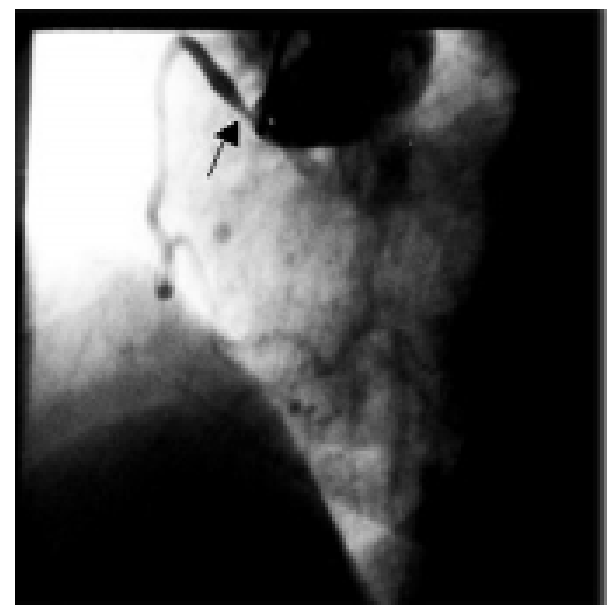

Fig. 2A - Pre-operative coronary angiography. 


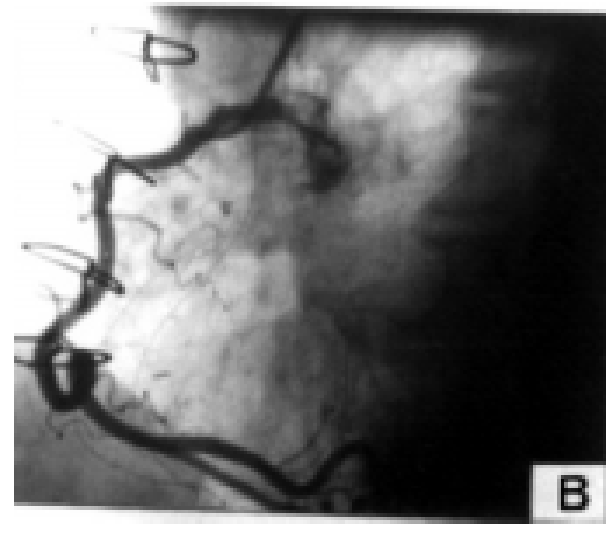

Fig. 2B - Post-operative coronary angiography

\section{COMMENTS}

Venous or arterial grafts consist of an excellent and safe procedure in the case of ostial obstruction of the right coronary artery, however, they present some potential limitations. Venous grafts suffer from degeneration and arterial grafts, due to several factors, can not always be used. Coronary ostial reconstruction procedures utilize homogenous $[3,4]$ or autologous [2,3] tissue susceptible to intimal hyperplasia, thrombosis and calcification.

The proposed technique of re-implantation of the right coronary artery is simply effected, avoids the use of patches and allows the suture of tissue without pathologic alterations, which permits an anastomosis with a high immediate and late permeability rate.

This technique can only be used when there is an isolated obstruction located in the ostium, and absence of anastomosis in the periosteal region. However, coronary ostial lesions are seen in $60 \%$ of the cases of isolated obstructions, in practically normal vessels, or with slight obstructions which permit implantation.

The absence of tissue patches and the anastomosis between tissues without alterations, probably, will determine the increased rate of penetrability over the long term.

The site of the new ostium after the re-implantation allows an easy catheterization, thus enabling possible future interventionist procedures.

A greater series of patients with a longer follow-up period is necessary to better evaluate this technique.

\section{BIBLIOGRAPHIC REFERENCES}

1 - Sabiston Jr. DC, Ebert PA, Friesinger GC, Ross RS, SinclairSmith B. Proximal endarterectomy, arterial reconstruction for coronary occlusion at aortic origin. Arch Surg 1965; 91: 758-64.

2 - Bortolotti U, Milano A, Balbarini A, Tartarini G, Levantino $\mathrm{M}$, Borzoni $\mathrm{G}$ et al. Surgical angioplasty for isolated coronary ostial stenosis. Tex Heart Inst J 1997; 24: 366-71.

3 - Dion R, Elias B, El Khoury G, Noirhomme P, Verhelst R, Hanet C. Surgical angioplasty of the left main coronary artery. Eur J Cardiothorac Surg 1997; 11: 857-64.

4 - Croti UA, Gregori Jr F, Marcial MB, Dallan LA, Gregori TE, Oliveira DS. Coronary bilateral ostial enlargement using the saphenous vein in a patient with syphilitic aortitis. Arq Bras Cardiol 2000; 74: 153-8.

5 - Liska J, Jönsson A, Lockowandt U, Herzfeld I, Gelinder S, Franco-Cereceda A. Arterial patch angioplasty for reconstruction of proximal coronary artery stenosis. Ann Thorac Surg 1999; 68: 2185-90. 